\title{
AMCoR
}

Asahikawa Medical College Repository http://amcor. asahikawa-med. ac. jp/

\section{INTERNATIONAL JOURNAL OF PEDIATRIC}

OTORHINOLARYNGOLOGY (2002) 63-3:199-207.

Decreased serum and pharyngeal antibody levels specific to streptococcal lipoteichoic acid in children with recurrent tonsillitis

Yokoyama, Y; Harabuchi, Y 
Decreased serum and pharyngeal antibody levels specific to streptococcal lipoteichoic acid in children with recurrent tonsillitis

Yuji Yokoyama, M.D. ${ }^{1}$; Yasuaki Harabuchi, M.D., Ph.D. ${ }^{2}$

${ }^{1}$ Tomakomai Otolaryngology Clinic, Shin-nakano 3-9-8, Tomakomai, 053-0006, Japan.

2 Department of Otorhinolaryngology, Asahikawa Medical College, Midorigaoka

E2-1-1-1, Asahikawa, 078-8510, Japan.

Running title: antibodies to lipoteichoic acid

Address for correspondence: Yasuaki Harabuchi, M.D., Ph.D., Professor and Chairman, Department of Otorhinolaryngology, Asahikawa Medical College, Midorigaoka E2-1-1-1, Asahikawa, 078-8510, Japan.

Phone: +81 (Japan)-166-68-2554 Fax: +81 (Japan)-166-68-2559.

E-mail: hyasu@asahikawa-med.ac.jp 


\section{Abstract}

Objective: Streptococcus (S.) pyogenes is common causes of primary as well as recurrent tonsillitis (RT). Lipoteichoic acid (LTA) has been proposed as a possible candidate for vaccine formulation against streptococcal infections, because LTA is a common constituent of streptococci and the antibody to LTA inhibits bacterial attachment to epithelial cells in vitro. Streptolysin-O and streptococcal whole cell body are highly immunogenic and the antibodies to these antigens are reported to be better parameters for streptococcal infections The objective of the present study is to investigate how systemic and local immune activities against $\mathrm{S}$. pyogenes may be associated with RT. M ethods: Sera from 178 children with or without RT aged 1-15 years with a median age of 5 years were investigated for the levels of total immunoglobulins and antibodies specific to streptococcal antigens such as whole cell body, LTA, and streptolysin-O. Pharyngeal secretions from 67 children with or without RT aged 2-14 years with a median age of 6 years were subjects to secretory $\operatorname{IgA}(\operatorname{SIgA})$ antibody levels to streptococcal LTA. The antibodies to whole cell body and LTA were measured by enzyme-linked immunosorbent assay. Total immunoglobins and the antistreptolysin-O antibody were assayed by nephelometry. Results: An age-matched comparison revealed that either levels of serum IgG antibody or pharyngeal SIgA antibody to streptococcal LTA at 2-5 years of age were significantly lower in RT children than in non-RT children ( 1.39 vs. $5.14 \mu \mathrm{g} / \mathrm{ml}, \mathrm{p}=0.001 ; 10.6$ vs. 29.9 units $/ \mathrm{ng} / \mathrm{ml}$ total SIgA, $\mathrm{p}=0.015$; respectively) and correlated inversely to episodes of tonsillitis $(\mathrm{r}=-0.242, \mathrm{p}=0.024 ; \mathrm{r}=-0.3, \mathrm{p}=0.024$; respectively). Either serum total immunoglobulin levels of $\operatorname{IgG}$ or IgA correlated positively to episodes of tonsillitis in children aged $2-5$ years $(r=0.293, p=0.011 ; r=0.361, p=0.002$; respectively). No difference was found on either serum levels of IgG antibody to streptococcal whole cell body or antibody to streptolysin-O between RT and non-RT children in any 
age-matched comparisons. High serum antibody levels to whole cell body was associated with high antibody levels to streptococcal LTA in non-RT children $(r=0.198$, $\mathrm{p}<0.05$ ), but no association was found between these antibody levels in RT children. Conclusions: Selective immunologic failure in systemic and pharyngeal antibody response to streptococcal LTA may be a potential cause of RT in young children.

Key Words: tonsillitis, antibody, lipoteichoic acid, streptococci 


\section{Introduction}

Recurrent episodes of acute tonsillitis is a common problem in infectious disorders during childhood. Bacterial adhesion to tonsillar or pharyngeal epithelium may be a potential cause of this recurrent phlogistic condition [1, 2]. Humoral immunity of the host may be an another cause of recurrent tonsillitis (RT). Increased serum levels of total IgG, IgA and IgM in children with RT has been reported previously [3]. On the other hand, pharyngeal secretory $\operatorname{Ig} \mathrm{A}(\mathrm{S} \operatorname{Ig} \mathrm{A})$ has been reported to be lower in children with RT [1].

Selective immunologic failures against Streptococcus (S.) pneumoniae, nontypeable Haemophilus influenzae(NTHi) and Moraxella (M .) catarrhalis have been investigated widely in young children with recurrent acute otitis media (ROM) [4-7] and with persistent otitis media with effusion (OME) $[8,9]$. Lower antibody response to pneumococcal polysaccharides of type $6 \mathrm{~A}$ and $19 \mathrm{~F}$ has been demonstrated in infants and children with ROM [4]. Our previous studies showed the failure of systemic and nasopharyngeal antibody responses as well as lower cellular immune response of adenoidal lymphocytes to P6 outer membrane protein of NTHi in children with ROM [5-7]. Young children with persistent OME have been also shown to be insufficient serum antibody response to $\mathrm{CD}$ outer membrane protein of M . catarrhalis, P6 protein, and pneumococcal polysaccharides $[8,9]$. However, specific immunologic activities against major pathogens of tonsillitis in children with RT have not been clarified yet.

S. pyogenes is common cause of primary as well as RT. Lipoteichoic acid (LTA), a constituent of the cell surface of most streptococci, is characterized as glycolipid-linked polymers of glycerol phosphate units [10, 11]. LTA is homogenous among strains and species in structure and antigenicity, and to act as a substance in the bacterial site for adherence to mucosa [12-15]. The antibody to LTA inhibits the bacterial adherence to epithelial cells in vitro $[12,13]$. The admistration of LTA from S. pyogenes enhances the IgA antibody synthesis in the lung of mice [16]. Therefore, LTA 
has been proposed as a possible candidate for vaccine formulation for S. pyogenes infections.

The aim of this study is to investigate immunologic activities against $\mathrm{S}$. pyogenes in children with RT. For this purpose, we measured serum antibody levels specific to whole cell body, LTA, and streptolysin-O from S. pyogenes. We also measured the levels of secretory IgA antibody to streptococcal LTA in pharyngeal secretion to determine local immunity.

\section{$M$ aterials and methods}

Subjects and samples

Serum samples were obtained from 178 children, 76 females and 102 males, aged 1-15 years with a median age of 5 years. Thirty-five of the subjects were diagnosed as RT because they had experienced 5 or more episodes of acute tonsillitis prior to one year period. The other 143 children experienced 4 or fewer episodes of acute tonsillitis prior to one year period. Age distributions according to episodes of tonsillitis are shown in Table 1. The diagnosis of acute tonsillitis was established by the appearance of hyperemic swelling or white plug formation of tonsils with acute inflammatory symptoms such as high fever, irritability, and throat pain. The samples were stored at $-80^{\circ} \mathrm{C}$ until use.

Pharyngeal secretions were obtained from 67 children aged 2-14 years with a median age of 6 years. Of these 67 children, 37 were from the above group that was subject to serum antibodies. The remaining 30 were subject to pharyngeal antibody alone. Twenty-six children had 5 or more episodes of acute tonsillitis prior to one year period and were classified as RT. The remaining 41 children had 4 or fewer episodes of acute tonsillitis prior to one year period. Age distributions according to episodes of tonsillitis are shown in Table 2 . The pharyngeal samples were collected by rinsing the 
pharynx with $10 \mathrm{ml}$ of sterile phosphate buffered saline (PBS) and then centrifuged immediately at $1,000 \mathrm{~g}$ for 5 minutes. The supernatant fluids were collected, filtered through a $0.45 \mu \mathrm{m}$ filter, and stored at $-80^{\circ} \mathrm{C}$ until use.

No child had suffered an episode of acute upper respiratory infection or received any antibiotics within 1 month before the serum or pharyngeal samples were taken. Informed consent was obtained from parents of participants at the time of enrollment into the study, which had received prior approval by the Institutional Review Board.

Preparation of streptococcal antigens

The lipoteichoic acid (LTA) purified from S. pyogenes using a phenolic extraction procedure was purchased from Sigma Immuno Chemical Co., St. Louis, Mo., USA. The lyophilized whole cell body from S. pyogenes type T12 WHOSF42 was prepared as follows. Bacteria were grown over night at $37^{\circ} \mathrm{C}$ in Todd Hewitt Broth (DIFCO laboratories, Detroit, Mich., USA) and incubated for 40 minutes at $60^{\circ} \mathrm{C}$. The inactivated cells were harvested by centrifugation at $9000 \mathrm{~g}$ for 30 minutes at $4{ }^{\circ} \mathrm{C}$, resuspended in PBS, and centrifuged in the same conditions. The pellets were then lyophilized over night in a Labconco(r) (Labconco Co., Kansas City, Mo., USA) and stored at $-80^{\circ} \mathrm{C}$ until use.

\section{M easurement of serum antibodies}

The serum levels of $\operatorname{IgG}, \operatorname{IgM}$, and $\operatorname{IgA}$ were assayed by nephelometry using $\mathrm{N}$-antiserum to human IgG, IgM and IgA (Behring Diagnostics, Marburg, Germany).

Serum antibody levels to LTA and to whole cell body of S. pyogenes were measured by enzyme-linked immunosorbent assay (ELISA) as described previously [5, $6,8,9]$. Breifly, the wells of flat-bottomed microplates (Nunc-Immuno Plate MaxiSorp, Roskilde, Denmark) precoated with $50 \mu 1$ of $10 \mu \mathrm{g} / \mathrm{ml}$ LTA or with $50 \mu 1$ of $5 \mu \mathrm{g} / \mathrm{ml}$ 
lyophilized whole $S$. pyogenes cell body were incubated with $50 \mu \mathrm{l}$ of appropriately diluted serum samples at in PBS containing 0.5\% Tween 20 and $0.5 \%$ gelatin (PBS-T-G) for 2 hours at $37^{\circ} \mathrm{C}$. Each sample was assayed in duplicate. The plates were then incubated sequentially with $50 \mu 1$ of appropriately diluted peroxidase-labeled rabbit anti-human IgG, IgA, and IgM (DAKO Immunoglobulins, Copenhagen, Denmark) in PBS-T-G for 2 hours at $37^{\circ} \mathrm{C}$. They were then reacted with $50 \mu 1$ of $10 \mathrm{mg} / \mathrm{ml}$ o-phenylenediamine (OPD: Sigma) for 15 minutes and the reaction was stopped by $5 \mathrm{~N}$ sulfuric acid. After each reaction, the plates were washed three times with PBS-T. The optical density of each well was measured with an automated spectrophotometer (Easy Reader EAR 400FW; SLT-Labinstruments, Grödig, Austria). A serial dilution curve was run on each plate with standard human $\operatorname{IgG}, \operatorname{IgM}$ or $\operatorname{IgA}$. The antibody value in the sample was read from the standard curve and expressed as an absolute concentration $(\mu \mathrm{g} / \mathrm{ml})$. The detectable levels of serum IgG antibodies to LTA and streptococcal whole cell body ranged from $0.19-22 \mu \mathrm{g} / \mathrm{ml}$ and $7.0-210 \mu \mathrm{g} / \mathrm{ml}$, respectively. The serum anti-LTA $\operatorname{IgM}$ and $\operatorname{IgA}$ antibodies were detectable at levels ranging from 0.06-30 $\mu \mathrm{g} / \mathrm{ml}$ and $0.05-10 \mu \mathrm{g} / \mathrm{ml}$, respectively.

The serum antibody to streptolysin-O was measured by latex nephelometry using an NA-latex ASL kit (Behring Diagnostics, Marburg, Germany). The lower limit of the detection in this assay was $50 \mathrm{IU} / \mathrm{ml}$.

\section{M easurement of pharyngeal anti-LTA secretory IgA antibody}

The level of pharyngeal anti-LTA secretory IgA antibody was also measured by ELISA as described above. The pharyngeal samples diluted 1:10 were applied and peroxidase-labeled rabbit anti-human secretory component (DAKO, Denmark) was used as a detection antibody. A serial dilution curve was run on each plate with pooled breast milk and used as a standard. The value of anti-LTA secretory IgA antibody was read from the serial dilution curve with pooled breast milk and expressed as relative 
units (100 times the dilution number of the pooled breast milk). One unit was $1 / 100$ of the corresponding antibody concentration in the pooled breast milk. The lower limit of detection in this assay was 2.2 units.

To standardize test values for potential dilutional differences between pharyngeal secretion samples, the levels of anti-LTA antibodies wee adjusted to a uniform secretory IgA level by dividing them by the total secretory $\operatorname{Ig} \mathrm{A}$ concentration and expressed as units per $\mathrm{ng} / \mathrm{ml}$ total secretory $\operatorname{IgA}$. The concentration of total secretory IgA was measured by ELISA. The rabbit anti-human IgA (alpha-chain specific) (DAKO) was used as a capture antibody. The lower limit of the assay was 300 $\mathrm{ng} / \mathrm{ml}$.

\section{Statistics}

The analyses were completed using appropriate nonparametric test procedures including the Mann-Whitney's U test and Spearmann's regression coefficient. Statistical tests were based on a level of significance of $\mathrm{p}<0.05$.

\section{Results}

Serum antibodies to streptococcal antigens in overall cases

Serum anti-LTA IgG antibody was detected in $169(95 \%)$ of 178 children (median:interquartile values=3.46:1.29-13.2 $\mu \mathrm{g} / \mathrm{ml}$ ). The $\operatorname{IgM}$ antibody was detected in all serum samples (0.89:0.38-1.53 $\mu \mathrm{g} / \mathrm{ml})$. The IgA antibody was under detectable level in all samples.

Serum IgG antibody to whole cell body was detected in $170(96 \%)$ of the 178 children. The levels $(88.7: 27-210 \mu \mathrm{g} / \mathrm{ml})$ were significantly higher than those of anti-LTA IgG antibody ( $\mathrm{p}<0.0001)$. Of 139 children in whom serum anti-streptolysin-O 
was assayed, $50(36 \%)$ showed detectable levels of the antibody (Table 3 ).

Serum antibodies to streptococcal antigens in $\mathrm{RT}$ and non-RT children

Figure 1 shows serum antibody levels according to age in 143 non-RT

children. During childhood the levels of serum total immunoglobulins, anti- LTA IgG and anti-whole cell body IgG antibody, were lowest at 1 year of age. The levels went up remarkably at 2-3 years of age and increased gradually until 8-9 years of age. The number of cases, in whom anti-streptolysin-O antibody was detected, was very small at 1-3 years of age, increased during 4-5 years of age, and reached about 50\% during 6-15 years of age (Table 3$)$.

Figure 2 shows age-matched comparison between RT and non-RT children. In contrast to the age-related increment of anti-LTA IgG antibody levels in non-RT children, the levels did not increase in RT children at 2-5 years of age. The antibody levels of RT children (1.39:1.02-3.87 $\mu \mathrm{g} / \mathrm{ml})$ tented to be lower compared to those of non-RT children $(3.53: 1.8-18.1 \mu \mathrm{g} / \mathrm{ml}, \mathrm{p}=0.073)$ at $2-3$ years of age. The difference was statistically significant at 4-5 years of age (1.51:0.21-3.54 vs. 5.39:1.61-17.8 $\mu \mathrm{g} / \mathrm{ml}$, $\mathrm{p}=0.008)$. However, the antibody levels were not different between RT and non-RT children during 6-15 years of age (Fig. 2a). The IgG antibody levels to LTA correlated inversely to episodes of tonsillitis in children aged $2-5$ years $(r=-0.242, p=0.024)$, but were not associated with the episodes in children aged 6-15 years $(\mathrm{r}=-0.016, \mathrm{p}=0.89)$. There was no correlation between episodes of tonsillitis and serum IgM antibody levels to LTA in any age-matched comparisons.

The levels of serum antibody to streptococcal whole cell body rose significantly at 2-5 years of age in both RT and non-RT children. The antibody levels were not different between RT and non-RT children at any age (Fig. 2b). The antistreptococcal whole cell body IgG antibody level was not correlated with episodes of tonsillitis either in children aged 2-5 years $(r=0.014, \mathrm{p}=0.89)$ or 6-15 years $(\mathrm{r}=-0.006$, 
$\mathrm{p}=0.96$ ). There was no difference in the levels of serum anti-streptolysin-O antibody between RT and non-RT children in any age-matched comparisons (Table 1).

When the relation between episodes of tonsillitis and total immunoglobulin levels was examined, either levels of $\operatorname{IgG}$ or IgA correlated positively to episodes of tonsillitis in children aged $2-5$ years $(r=0.293, p=0.011 ; r=0.361, p=0.002$; respectively), but total IgM level was not correlated $(\mathrm{r}=0.168, \mathrm{p}=0.14)$. There was no correlation between total immunoglobulins of any classes and episodes of tonsillitis in children aged 6-15 years $(\operatorname{IgG}: \mathrm{r}=0.008, \mathrm{p}=0.9 ; \operatorname{IgA}: \mathrm{r}=0.01, \mathrm{p}=0.4 ; \operatorname{IgM}: \mathrm{p}=-0.1, \mathrm{p}=0.3)$.

Pharyngeal secretory IgA (SI gA) antibody to LTA

The median and interquartile values of total SIgA in pharyngeal secretions was 9.7 and 5.0-18.6 $\mu \mathrm{g} / \mathrm{ml}$, respectively. There was no correlation between pharyngeal total SIgA and episodes of tonsillitis $(\mathrm{r}=-0.1, \mathrm{p}=0.5)$.

The SIgA antibody to LTA was detected in all 67 pharyngeal secretions. The antibody level was 17.4:9.7-45.5 units/ng/ml total SIgA. An age-matched comparison showed that the levels of SIgA antibody to LTA were significantly lower in RT children than in non-RT children at both 2-5 years (10.6:2.90-14.4 vs. 29.9:11.0-55.8 units/ng/ml total SIgA, $\mathrm{p}=0.015)$ and 6-15 years of age (9.46:3.09-27.7 vs. 33.0:15.9-64.3 units/ng/ml total SIgA, p=0.028; Fig. 3). Pharyngeal SIgA antibody levels to LTA correlated inversely to episodes of tonsillitis $(\mathrm{r}=-0.3, \mathrm{p}=0.024)$,

\section{Relationships among antibody levels to str eptococcal antigens}

The cases in whom serum anti-streptolysin-O antibody was detected showed significantly higher serum IgG antibody levels to streptococcal whole cell body than the cases in whome serum anti-streptolysin-O antibody was not detected in both non-RT children $(210: 192-210(\mathrm{n}=41)$ vs. 41.7:20.4-108 $(\mathrm{n}=69) \mu \mathrm{g} / \mathrm{ml}, \mathrm{p}<0.0001)$ and in RT children $(166: 131-210(\mathrm{n}=9)$ vs. 40.0:14.9-93.0 $(\mathrm{n}=20) \mu \mathrm{g} / \mathrm{ml}, \mathrm{p}=0.005)$. There was a 
significant positive correlation between IgG antibody levels specific to streptococcal whole cell body and to streptococcal LTA in non-RT children $(r=0.198, p<0.05)$; however the correlation was not found in RT children $(\mathrm{r}=0.03, \mathrm{p}=0.9)$. There was no correlation between the anti-streptococcal LTA antibody levels of serum IgG and pharyngeal $\operatorname{SIgA}(\mathrm{n}=37, \mathrm{r}=-0.06, \mathrm{p}=0.72)$.

Discussion

It is general accepted that humoral immunity of the host is one of the pathogenic factors of RT. Increased serum levels of total $\operatorname{IgG}, \operatorname{Ig} \mathrm{A}$, and $\operatorname{IgM}$ in children with RT have been reported [3]. On the other hand, pharyngeal secretory $\operatorname{Ig} \mathrm{A}(\mathrm{S} \operatorname{IgA})$ has been reported to be lower in children with RT [1]. Although S. pyogenes is a common pathogen for acute tonsillitis, specific antibody responses against this pathogen is little known yet. The purpose of this study was to clarify this area, assisted by specific antibody levels to several S. pyogenes antigens in sera and pharyngeal secretions.

In this study, we chose streptolysin-O, LTA, and lyophilized whole bacterial cell body as antigens of S. pyogenes. Streptolysin-O characterized as an oxygen-labile hemolysin is one of a variety of extracellular products elaborated by group A streptococci [17]. Streptolysin-O has a highly immunogenic activity and elicits an antibody response in the host during a group A streptococcal infection. The antibody to streptolysin-O is used as a marker for preceding streptococcal infection, but the antibody has no bactericidal activity [17]. The lyophilized whole bacterial cell body, which contains peptideglycan, polysaccharide, and the other constituents of the bacterial cell body, is highly immunogenic and the antibody to this antigen has been reported to be a better parameter for streptococcal infections [18].

Lipoteichoic acid (LTA), characterized as glycolipid-linked polymers of glycerol phosphate units, is a common constituent of the cell surface of most gram 
positive bacteria $[10,11]$. LTA is reported to act as a substance in the bacterial site for adherence to epithelium $[12,13]$. The antibody to LTA is reported to have cross-reactivity among a wide variety of gram positive bacteria $[14,15]$ and to inhibit in vitro attachment of the organisms to epithelial cells $[12,13]$. The admistration of LTA from S. pyogenes enhances the IgA antibody synthesis in the lung of mice [16]. For these reasons, LTA has been proposed as a potential candidate for inclusion in a vaccine. Healthy adults have shown sufficient production of anti-LTA antibody in sera during local or systemic infection with streptococci $[19,20]$.

In our study, the levels of serum total immunoglobulins and anti-whole $\mathrm{S}$. pyogenes cell antibody went up remarkably at 2-3 years of age and increased gradually until 8-9 years of age in non-RT children. A similar age-related change was seen in anti-LTA antibodies. These facts concur with the data observed previously in normal children [21]. On the other hand, in RT children, serum anti-streptococcal LTA IgG antibody did not increase at 2-5 years of age, in spite of a significant increment of the levels of total immunoglobulins and anti-whole S. pyogenes cell antibodies. An age-matched comparison revealed that RT children had serum antibodies to streptolysin-O and whole S. pyogenes cell body at similar levels of non-RT children; however, RT children showed significantly lower levels of the IgG antibody to streptococcal LTA in sera than non-RT children at 2-5 years of age. When relationships between episodes of tonsillitis and the immunoglobulin or antibody levels were examined, high levels of total IgG and IgA were related to frequent episodes of tonsillitis. This is in correspondence with the data previously shown in elsewhere [3]. On the other hand, low anti-LTA antibody levels were associated with frequent episodes of tonsillitis in children aged 2-5 years. Bacterial colonization as well as antigen specific humoral immunity may influence the specific antibody production. Although we did not attempt to examine bacterial culture, it seems certain that children with recurrent phlogistic conditions in the upper respiratory tracts expose to streptococci 
more frequently. Furthermore, in RT children, high antibody levels to whole cell body were associated with high anti-streptolysin-O antibody levels, but there was no association between the levels of anti-whole cell body antibody and anti-LTA antibody. It is suggested, on the basis of the data, that selective immunologic failure may be present in response to streptococcal LTA in young children with RT. The positive correlation among the antibody levels to streptococcal whole cell body, streptolysin-O and LTA in non-RT children may represent sufficient response to these 3 types of streptococcal antigens.

Bacterial adherence to epithelium may be another determinant for recurrent tonsillitis. Several reports have demonstrated increased attachment of S. pyogenes to tonsillar or pharyngeal epithelium during acute tonsillitis [2]. Local immunity may be one of the host factors that inhibits bacterial adherence. Secretory $\operatorname{IgA}$ is known to be the predominant immunoglobulin in nasopharyngeal secretions and to play a role in the inhibition of bacterial adherence to nasopharyngeal mucosa. Although there have been several reports about total secretory IgA levels in pharyngeal secretion during the recurrent phlogistic condition, the results were not uniform $[1,22]$. In the present study, total secretory $\operatorname{IgA}$ levels in pharyngeal secretion were not different between RT and non-RT children; while the levels of pharyngeal secretory $\operatorname{IgA}$ antibody to streptococcal LTA correlated inversely to episodes of tonsillitis and were significantly decreased in RT children. It has been reported that in vitro streptococcal adherence to human buccal cells or hydroxyapatite was significantly reduced by treatment with anti-LTA antibody, demonstrating that the antibody had an inhibiting activity against bacterial adherence to epithelium $[12,13]$. Recently, we observed that intranasal immunization with streptococcal LTA induced either systemic or pharyngeal antibody responses and inhibited streptococcal adherence to pharyngeal epithelium in mice [23]. It is suggested on the basis of these data, that insufficient production of pharyngeal anti-LTA SIgA antibody, which might contribute to increased streptococcal attachment to pharyngeal 
epithelium, may potentially cause the recurrence of acute tonsillitis.

In the present study, we failed to find a correlation between serum and pharyngeal levels of the anti-LTA antibodies in any of the subjects studied. This corresponded to the data previously reported elsewhere $[22,24]$. Pharyngeal antibody is likely to be produced locally after direct antigenic stimulation at the mucosal surface, prior to appearance of serum antibodies [25].

In summary, we showed clearly that young children with RT had a decreased rise in serum anti-LTA IgG antibody and in pharyngeal anti-LTA SIgA antibody, and there was no real correlation of serum in pharyngeal secretion levels. Children with ROM or persistent OME have been shown also to exhibit insufficient antibody responses to pneumococcal polysaccharides of type 6A and 19F [4], P6 protein of NTHi [5, 6], and CD protein of M. catarrhalis [8], and the poor response to these antigens has been attributed to their weak immunogenicity [26]. The anti-LTA antibody level showed only one hundredth fold levels of anti-whole cell body antibody, which concurred with results shown elsewhere [27, 28], suggesting that the immunogenicity of LTA may be weak. In view of these findings, it is possible that such children may not recognize weak immunogens. However, we really do not know enough about the developing immune system to call this immune failure. There has clearly been some effect of RT in decreasing antibody responses to this streptococcal antigen and this may be used as a marker for these patients. Further investigation is warranted.

\section{References}

[1] Galioto GB, Mevio E, Maserati R, Galioto P, Galioto S, Dos Santos C, et al. Bacterial adherence and upper respiratory tract disease: a correlation between S. pyogenes attachment and recurrent throat infections. Acta Otolaryngol Suppl Stockh. 1988;454:167-74. 
[2] Lilja M, Myklebust R, Räisänen S, Stenfors LE. Selective attachment of beta-haemolytic streptococci group A to oropharyngeal epithelium in health and disease. Acta Otolaryngol (Stockh). 1997;117:744-9.

[3] Lal H, Sachdeva OP, Mehta HR. Serum immunoglobulins in patients with chronic tonsillitis. J Laryngol Otol. 1984;98:1213-6.

[4] Prellner K, Kalm O, Pedersen FK. Pneumococcal antibodies and complement during and after periods of recurrent otitis. Int J Pediatr O torhinolaryngol. 1984;7:39-49.

[5] Yamanaka N, Faden H. Antibody response to outer membrane protein of nontypeable Haemophilus influenzae in otitis-prone children. J Pediatr. $1993 ; 122: 212-8$.

[6] Harabuchi Y, Faden H, Yamanaka N, Duffy L, Wolf J, Krystofik D.

Nasopharyngeal colonization with nontypeable $\mathrm{H}$ aemophilus influenzae and recurrent otitis media. J Infect Dis. 1994;170:862-6.

[7] Kodama H, Faden H, Harabuchi Y, Kataura A, Berstein JM, Brodsky L. Cellular immune response of adenoidal and tonsillar lymphocytes to the P6 outer membrane protein of nontypeable Haemophilus influenzae in children with otitis media. Acta Otolaryngol (Stockh). 1999;119:377-383.

[8] Harabuchi Y, Murakata H, Goh M, Kodama H, Kataura A, Faden H, et al. Serum antibodies specific to $\mathrm{CD}$ outer membrane protein of M oraxella catarrhalis, P6 outer membrane protein of non-typeable Haemophilus influenzae and capsular polysaccharides of Streptococcus pneumoniae in children with otitis media with effusion. Acta O to-Laryngologica. 1998;118:826-32.

[9] Takada R, Harabuchi Y, Himi T, Kataura A. Antibodies specific to outer membrane antigens of M oraxella catarrhalis in sera and middle ear effusions from children with otitis media with effusion. Int J Pediatr Otorhinolaryngol. 1998;46:185-195. 
[10] Wicken AJ, Knox KW. Lipoteichoic acids: a new class of bacterial antigen. Science. 1975;187:1161-1167.

[11] Ward JB. Teichoic and teichuronic acids: biosysnthesis, assembly, and location. Microbiol Rev. 1981;45:211-243.

[12] Ofek I, Beachey EH, Jefferson W, Campbell GL. Cell membrane-binding properties of group A streptococcal lipoteichoic acid. J Exp M ed. 1975;141:990-1003. [13] Bolton RW. Adherence of oral streptococci to hydroxyapatite in vitro via glycerol-teichoic acid. Arch Oral Biol. 1980;25:111-4.

[14] Hamada S, Furuta T, Okahashi N, Nisizawa T, Yamamoto T, Chiba J.

Characterization of a monoclonal antibody specific for lipoteichoic acid from various gram-positive bacteria. Microbiol Immunol. 1984;28:1009-21.

[15] Knox KW, Markham JL, Wicken AJ. Formation of cross-reacting antibodies against cellular and extracellular lipoteichoic acid of Streptococcus mutans BHT. Infect Immun. 1976;13:647-52.

[16] Kofler N, Wolf H. [Stimulation of synthesis of secretory immunoglobulin A in the lung by oral immunization: an approach with therapeutic relevance?]. Wien K lin Wochenschr. 1996;108:432-7.

[17] Rosan B. The streptococci. In: Newman MG, Nisengaed R, eds. Oral microbiology and immunology. Philadelphia: W. B. Saunders Co.; 1988:145-166. [18] Jarlov JO, Christensson B, Espersen F, Hertz JB, Hedström S. Antibody response against whole Staphylococcus aureus in patients with staphylococcal septicaemia and endocarditis investigated by ELISA. Acta Pathol M icrobiol Immunol Scand B. $1985 ; 93: 307-13$

[19] Monefeldt K, Tollefsen T. Serum IgG antibodies reactive with lipoteichoic acid in adult patients with periodontitis. J Clin Periodontol. 1989;16:519-24.

[20] Russell MW, Wu HY, White PL, Kilian M, Henrichsen J. Serum antibody responses to Streptococcus mutans antigens in humans systemically infected with oral 
streptococci. Oral Microbiol Immunol. 1992;7:321-5.

[21] Jarlov JO, Espersen F, Christensson B, Jensen BA, Hedström S, Hertz JB. Antibody response to whole cells and teichoic acid of Staphylococcus aureus strain E 1369 in human sera. Acta Pathol Microbiol Immunol Scand B. 1987;95:115-20.

[22] Sørensen CH, Nielsen LK. Nasopharyngeal secretory immunoglobulins in children with recurrent acute otitis media and secretory otitis media. Apmis. 1988;96:199-205.

[23] Yokoyama Y, Harabuchi Y. Intranasal immunization with lipoteichoic acid and cholera toxin evokes specific pharyngeal IgA and systemic IgG responses and inhibits streptococcal adherence to pharyngeal epithelial cells in mice. Int J Ped Otorhinolaryngol. In press

[24] Yamanaka N, Faden H. Local antibody response to P6 of nontypable Haemophilus influenzae in otitis-prone and normal children. Acta O tolaryngol Stockh. 1993;113:524-9.

[25] Pichichero ME, Hall CB, Insel RA. A mucosal antibody response following systemic Haemophilus influenzae type B infection in children. J Clin Invest. 1981;67:1482-9.

[26] Douglas RM, Paton JC, Duncan SJ, Hansman DJ. Antibody response to pneumococcal vaccination in children younger than five years of age. J Infect D is. 1983;148:131-7.

[27] Hamada S, Michalek SM, Torii M, Morisaki I, McGhee JR. An enzyme-linked immunosorbent assay (ELISA) for quantification of antibodies to Streptococcus mutans surface antigens. M ol I mmunol. 1983;20:453-64.

[28] Challacombe SJ, Bergmeier LA, Czerkinsky C, Rees AS. Natural antibodies in man to Streptococcus mutans: specificity and quantification. Immunology. 1984;52:143-50. 
Yokoyama Y. $-18-$

\section{Acknowledgments}

We thank honorary Prof. Kataura from Department of Otolaryngology,

Sapporo Medical University, Sapporo, Japan for kind support in this work. This work was supported by a Grant-in-Aid for Scientific Research from the Ministry of Education, Science and Culture of Japan. 


\section{Figure legends}

Figure 1. The levels of total immunoglobulins (a), IgG antibodies to streptococcal lipoteichoic acid (LTA) and to streptococcal whole cell body (b) in sera from non-RT children in relation to age. Data are expressed as median with interquartile.

Figure 2. Age-matched comparisons of serum IgG antibody levels to streptococcal lipoteichoic acid (LTA)(a) and to streptococcal whole cell body (b) between children with recurrent tonsillitis (RT) (J) and non-RT children (E). The serum anti-LTA antibody levels of RT children (J) tended to be lower at 2-3 years of age $(* \mathrm{p}=0.073)$ and were significantly lower at $4-5$ years of age $(* * \mathrm{p}=0.008)$ as compared to those of non-RT children (E) (Fig. 2a). On the other hand, there was no difference of serum anti- streptococcal whole cell body IgG antibody levels between RT (J) and non-RT (E) children at any age-matched comparisons (Fig. 2b). The antibody levels are expressed as log scale. The median values are expressed as short bar (-). Mann-Whitney's U test was used to determine p-value.

Figure 3. Pharyngeal secretory $\operatorname{IgA}(\mathrm{SIg} A)$ antibody levels to streptococcal lipoteichoic acid (LTA) in children with recurrent tonsillitis (RT) (J and non-RT children (E). The antibody levels are expressed as log scale. The median values are expressed as short bar (-). Mann-Whitney's U test was used to determine p-value. $* \mathrm{p}=0.015, * * \mathrm{p}=0.028$. 
a.
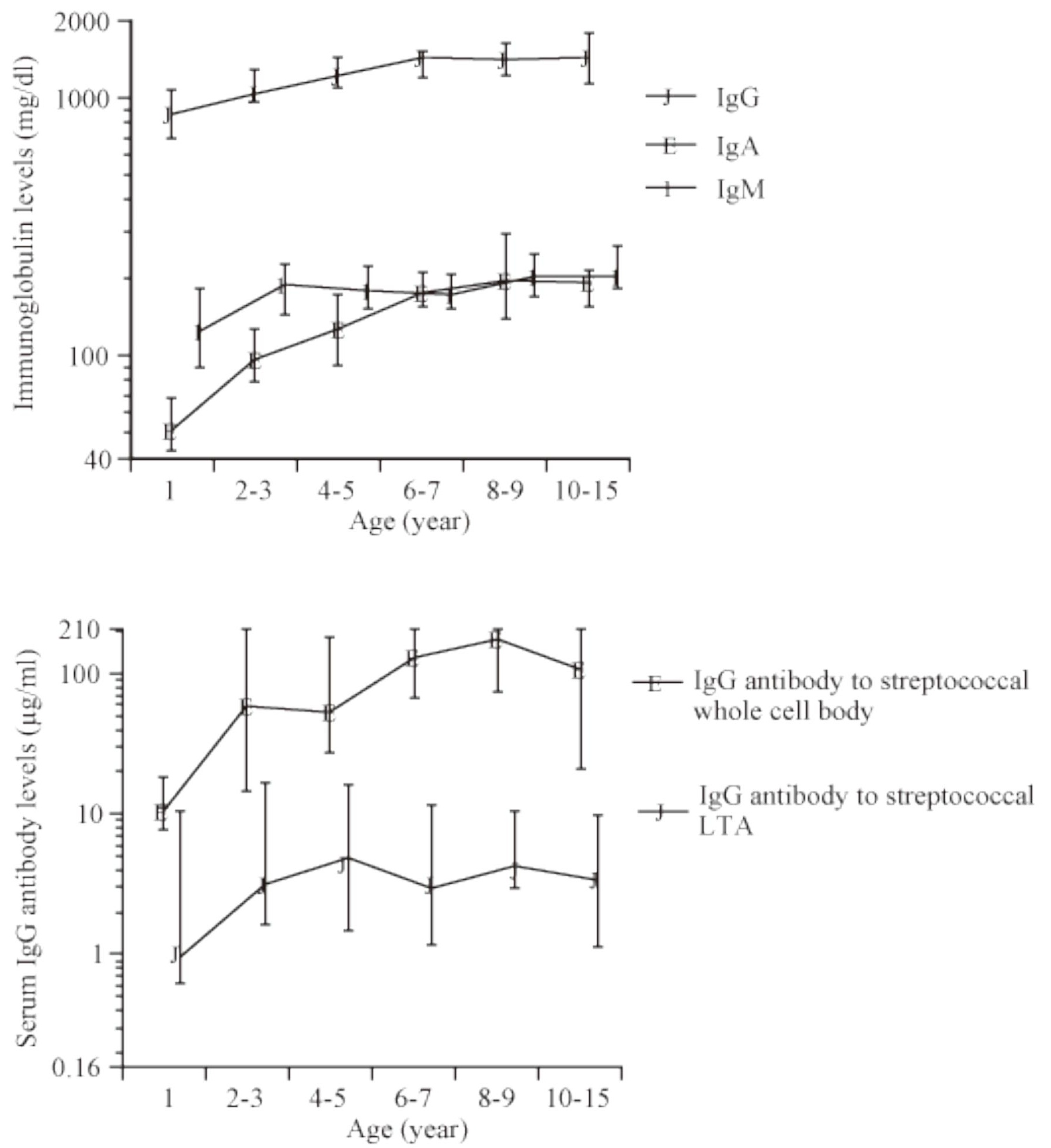
Figure 2

a

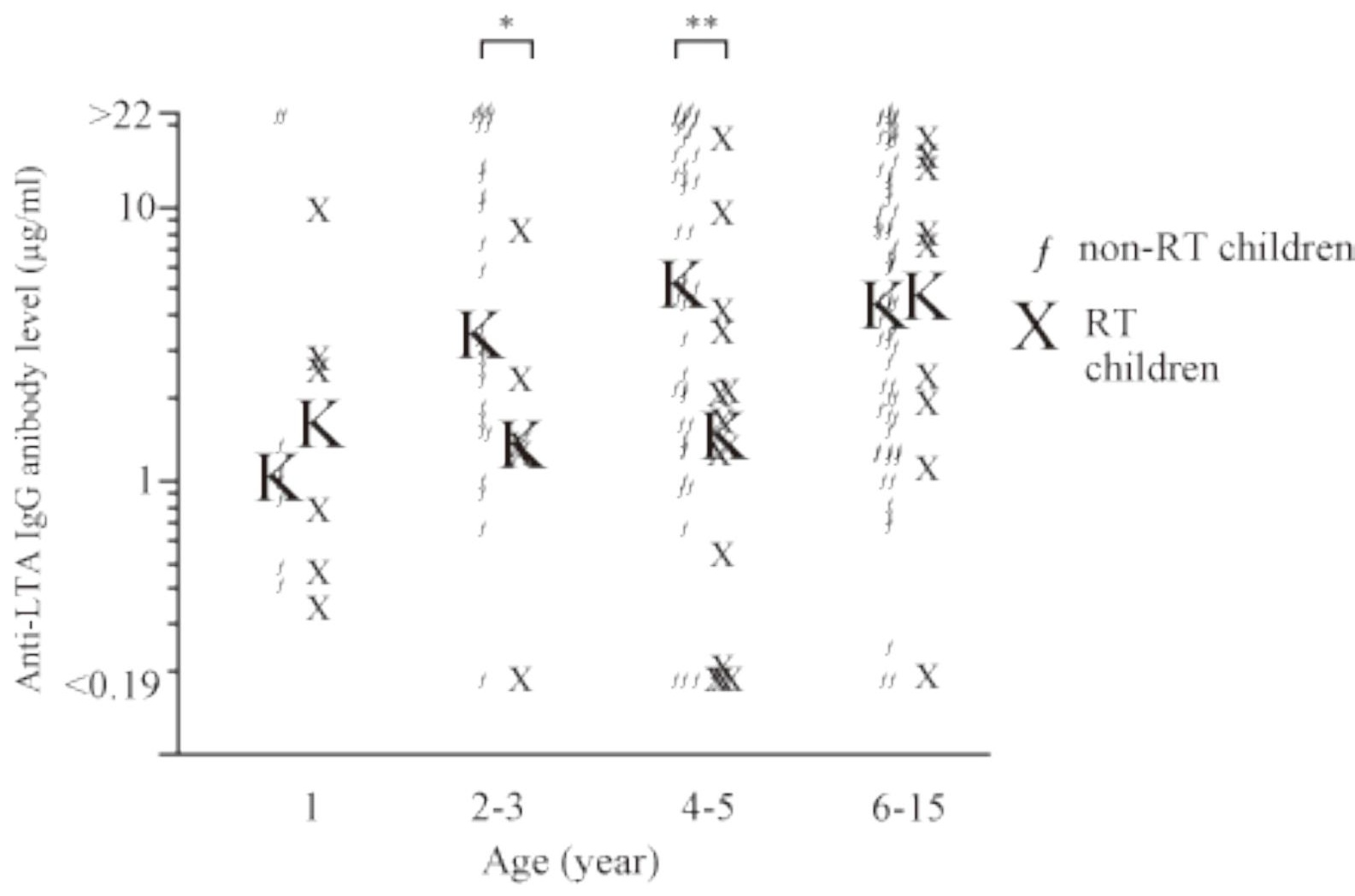

严
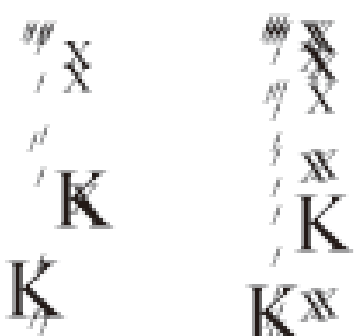

X

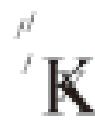

$\mathrm{X}$

$\mathrm{KX}^{\mathrm{X}}$

ix

$11^{8}$

$f$ non-RT children

$f_{\mathrm{X}}^{\mathrm{X}}$

X RT

children

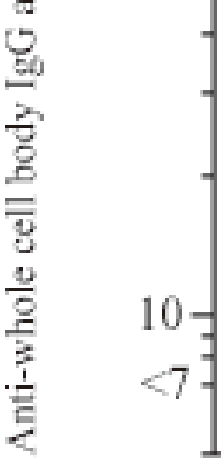

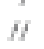

)

if $\mathrm{X}$

$\mathrm{X}$

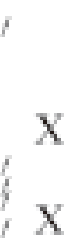

\& $\mathrm{X}$

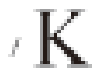

$\mathrm{X}$

if $\mathrm{X}$

,

$\mathrm{X}$

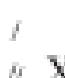



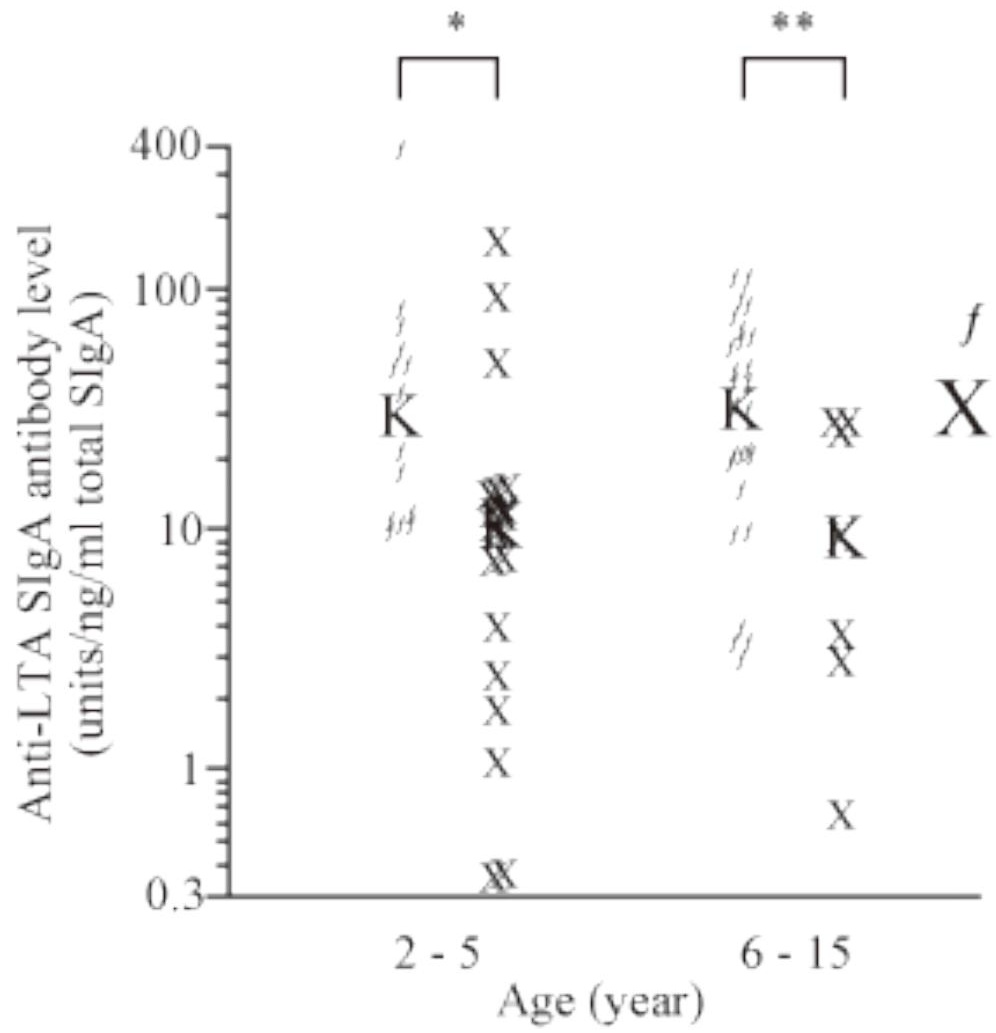

$f$ non-RT children

RT children 